\title{
Sulfhydryl Oxidase 2
}

National Cancer Institute

\section{Source}

National Cancer Institute. Sulfhydryl Oxidase 2. NCI Thesaurus. Code C158492.

Sulfhydryl oxidase 2 (698 aa, $78 \mathrm{kDa}$ ) is encoded by the human QSOX2 gene. This protein plays a role in the oxidation of sulfhydryl groups to disulfides in extracellular peptides and proteins. 